\title{
The Effect of Trade Liberalization on Regional Employment Adjustment: Evidence from China
}

\author{
Xiaofang Zhang ${ }^{1}$ \\ ${ }^{1}$ School of International Trade and Economics, Central University of Finance and Economics, P. R. China \\ Correspondence: Xiaofang Zhang, School of International Trade and Economics, Central University of Finance \\ and Economics, Beijing 100081, P. R. China. E-mail: zhxf25@foxmail.com
}

Received: April 8, 2019

Accepted: April 26, 2020

Online Published: April 29, 2020

doi:10.5539/ijbm.v15n5p193

URL: https://doi.org/10.5539/ijbm.v15n5p193

\begin{abstract}
Based on the exogenous event of China's accession to the World Trade Organization, using the data of tariff and employment in 2000 and 2010, this paper divides employment into formal and informal employment and studies the impact of lower tariff of final and intermediate goods on the employment change of China's labor market at the city level. It can be seen from the empirical results that the more the tariff of the main industries in a region falls, the greater the growth of total employment and informal employment in the region. The temporary nature of informal employment makes it more responsive to shocks of liberalization at first, while the formal may lag. The eastern coastal areas of China have more developed economy and its industrial emphasis facing larger tariff cuts, while the western areas are relatively less developed and its industrial emphasis facing smaller tariff cuts. Correspondingly, the employment situation in the eastern areas is relatively prosperous, absorbing a large number of informal employments.
\end{abstract}

Keywords: Trade liberalization, formal employment, informal employment

\section{Introduction}

Since the reform and opening up, the gradual evolution of China's foreign policy and foreign trade has had a profound impact on the regional coordinated development of China's economy. China's reform and opening-up policy has been implemented in different regions at different times, moreover, provinces and cities in China have complex terrain, diverse climate, different geographical advantages and economic and social development levels. Which results in different industrial structures and development levels of different provinces and cities. These inborn differences, coupled with the imbalance of the postnatal economic and trade policies, make the costs and gains of China's provinces and cities in the process of trade liberalization vastly different (Zhang et al., 2014; Zhang, 2015). After China's accession to the WTO in December 2001, its weighted average tariff rate dropped from $15.3 \%$ in 2001 to $4.4 \%$ in 2018. In 2018, Chian's total trade volume is about 4.623 trillion US dollars. Among them, the export volume is about 2.487 trillion US dollars, accounting for $12.8 \%$ of the global export volume, and the import volume is 2.136 trillion US dollars, accounting for $10.8 \%$ of the global import volume. As the largest exporter and the second-largest importer, the final goods tariff and intermediate input tariff have different impacts on the Chinese regional economy and labor market.

At the same time, China's labor force is large in number, complex in structure and uneven in distribution. With the gradual progress of reform and opening up and trade liberalization, the development of the labor market is also affected by the above factors. A large number of surplus labor in the central and western regions transfer to the southeast coastal areas, and the labor force in the same province or region moves from small cities to large cities. These phenomena lead to the imbalance and insufficiency development of China's labor market between regions and within regions. Research by Zhang Chuanchuan (2015) and Zhou Shen and He Bing (2017) shows that trade liberalization will lead to labor mobility between different regions and sectors, and the reallocation of such resources can reshape the structure of China's labor market. The increase of the number of private enterprises and foreign-funded enterprises has provided a large number of employment opportunities for the society, attracting a large number of rural surplus labor and urban freelancers to these enterprises, and the scale of informal employment in China has expanded rapidly. Informal employment is more convenient and flexible than formal employment, but it also has its inherent disadvantages. it is vulnerable to risks because it is isolated from the social security system, and its employment quality is generally not high. The existence of these 
characteristics requires us not only to understand the impact of trade liberalization on the formal labor market, but also to understand its impact on the informal labor market. Only in this way can we make more precise changes in our labor market and better cope with changes in international trade policies.

Due to data constraints and other reasons, the existing research on the labor market effect of trade liberalization mostly focuses on the whole or formal labor market at the country or province level. However, considering the imbalance of China's regional economic development (even within the same province, the differences between large and small cities are very obvious), It is necessary to conduct research at a micro-level. In addition, in the measurement of the labor market situation, the relative scale, the employment tendency of individual residents or other indicators are often used, but there is less discussion on the absolute scale of employment in the labor market. Moreover, most of the discussions are about the impact of the liberalization of final goods trade, while there are few studies on the liberalization of intermediate goods trade and informal labor market. Under this background, this paper constructs the regional level indicators of trade liberalization of final goods and intermediate goods respectively, to investigate the impact of output tariff and input tariff on regional total employment, formal and informal employment labor market.

Compared with the existing research, this paper has the following contributions. First, the existing literature mainly studies the relationship between trade liberalization and the overall employment or formal employment adjustment of a domestic regional labor market from the perspective of import competition. This paper divides the regional labor market employment into formal and informal employment, and studies the impact of trade liberalization on the employment of labor market in the city-level from a regional perspective. Secondly, the existing research only focuses on the impact of trade liberalization of final products on China's labor market. Considering that there is a large number of processing trade in China, the prosperity of processing trade may be an important channel to promote the employment of China's labor force, and there may be differences in the channels and extent of trade liberalization of intermediate and final products affecting China's regional labor market. Therefore, this paper examines the impact of final goods and intermediate goods trade liberalization on total employment, formal and informal employment in China's region labor market.

\section{Literature Review}

In the traditional trade theory and empirical research, people mostly pay attention to the labor market effect of trade liberalization at the nation and industry level, or the impact of labor employment changes at different skill levels. With Melitz (2003) put forward the theory of heterogeneous trade, economists turn their attention to the micro field, that is, the change of labor market structure of enterprises. Topalova (2010), Autor et al (2013), Dix Carneiro and Kovak (2015), Costa et al (2016), Zhang Mingzhi, et al. (2014), Zhang Chuanchuan (2015), Zhou Shen and he Bing (2017) all studied and analyzed the regional labor market effect of international trade. They believe that different regions in a country have different levels of industrial specialization, which makes these regions face different impacts in the process of trade liberalization policy adjustment. The greater the impact of trade liberalization policy, the greater the impact on the labor market. The studies of Kovak (2013), Dix Carneiro and Kovak (2017) show that the liberalization of final product trade will lead to the inconsistency of product price levels in different regions, which will lead to the difference of employment and wage adjustment in labor market in different regions, but these studies focus on the impact of the liberalization of final product trade on regional labor market. Dix Carneiro and Kovak (2019) studied the impact of trade liberalization on informal employment in Brazil from the perspective of import competition, while most of the existing literature focuses on the impact of trade liberalization on regional formal labor market.

Zhang Chuanchuan (2015) pointed out that export trade liberalization is positively related to the employment and wage level of the labor market, and export trade will improve the income inequality within the region. $\mathrm{Li}$ Jinchang et al. (2014) used China's provincial data from 2000 to 2012 and found that trade liberalization improved the relative scale of informal employment, and pointed out that the impact of import trade was greater than that of export trade. Zhou Shen and He Bing (2017) pointed out that after China's accession to the WTO, the liberalization of import trade has increased the probability that residents choose to participate in informal employment, and studied its regional characteristics. It was found that the higher the degree of trade liberalization is, the more residents tend to participate in informal employment. The study also points out that the informal employment effect of trade liberalization is heterogeneous, and the residents from the lower level of rural skills are more vulnerable to the impact of trade liberalization. Arias et al. (2018) pointed out in the study that after trade liberalization, the price of products in the domestic market dropped, a large number of idle labor released from the manufacturing industry. Because the cost of informal employment is far lower than that of formal employment, these idle labor will turn to the informal labor market to seek employment opportunities, resulting in an increase in the share of informal employment in the labor market structure. 


\section{Methodology}

\subsection{Economic Model}

Based on the research of Dix Carneiro and Kovak (2019), we set the following regression equation to test the relationship between trade liberalization and employment adjustment of regional labor market:

$$
\Delta L_{c}=\beta_{0}+\beta_{1} R T C_{c}+\beta_{2} X_{c, 2000}+\gamma_{p}+\varepsilon_{c}
$$

Among which, $\Delta L_{c}$ is the change of total employment, formal employment and informal employment of City c in 2010 compared with 2000. $R T C_{c}$ is the change of each city's tariff level in 2000-2010. $X_{c}, 2000$ represents a series of control variables, mainly the economic and social characteristic variables that may have an impact on urban employment in 2000. Imitating the settings of He Bing and Zhou Shen (2019), the control variables include the proportion of migrant population at the beginning of the period, the situation of human capital and the proportion of rural household registration population. These data comes from China's 2000 census data by county. $\gamma_{p}$ is the fixed effect at the province level, and $\varepsilon_{c}$ is the error term.

\subsection{Data}

The concept of informal employment originated from the International Labor Organization (ILO). For China, Shanghai first proposed the concept of "informal employment" in the document "some policies on the pilot work of reemployment project" in 1996. For a long time, scholars have been refining and developing the concept, and the definition of the concept has gradually changed from abstract to concrete, but there is still no unified definition standard. According to Liu Yanbin, the informal employment group is mainly engaged in the individual economy or private economy, and there are a large number of seasonal workers, temporary workers and other diverse ways of employment. Hu Angang said that the informal employment group can be divided into private enterprise employees in urban employment, individual economic employees and a large number of agricultural transfer workers who are mainly engaged in informal employment but not included in the statistical part. In this paper, we use the data statistical standards in China urban statistical yearbook to treat non-agricultural industry employment with establishment (bianzhi) as formal employment, and the difference between non-agricultural total employment and formal employment as informal employment. Informal employment is the sum of private employment, individual employment and unregistered employees.

Because of the difference of geographical location, environment and economic development level of Chinese cities, the differences between cities are obvious, even in the same province. But the physical location of the same city is relatively concentrated, and the economic development is more collaborative, so this paper studies the labor market effect of trade liberalization in 262 cities in China. The data sources used in the study mainly include China census data by county, the 5th census micro data in 2000, China Urban Statistical Yearbook, and HS-6 digit tariff data from the World Bank WITS database. We use the above data to calculate tariff indicators and total employment, formal employment and informal employment indicators at the city level.

\subsubsection{Employment Data}

(1) From the long table of China's census data by county, we can obtain the number of employees of each industry and permanent residents aged 15 and above of each city. This table provides a long list of $10 \%$ of the population. We can calculate the proportion of employment in the total industries and each industry in the permanent population aged 15 and above.

(2) According to the short table of China's census data by county, we can use the "total population" and "proportion of the population in each age group" to calculate the number of resident population aged 15 and above in each city.

(3) Using the results of step (1) and (2), we can calculate the number of employment of total industries and each industry in each city. This number of employment is the sum of formal and informal employment.

(4) From China Urban Statistical Yearbook of the year 2000 and 2010, we can obtain the number of formal employment with establishment (bianzhi) of all industries of each city. Then using the results of step (3), we can calculate the informal employment of all industries of each city.

According to the above steps, we can calculate the total employment change, formal employment change and informal employment change of sample cities in 2000-2010. 


\subsubsection{Tariff Data}

The tariff data used in this paper is from HS 6-digit level tariff data of the World Bank WTIS database. During the statistical period, the HS product code has been adjusted. According to the code comparison table of different versions of the World Customs Organization (WCO), we changed the different HS code to HS2002. Then, we use the method of Brandt et al (2017) to map the HS2002 code of the original tariff data to the national economic industry classification (CIC-4) of GB/t4754-2002, and get the output tariffs at the 4-digit level of CIC. To avoid any bias in the industry average due to low trade volumes in heavily protected product lines, we use an unweighted average.

The input tariffs are a weighted average of output tariffs. The calculation method is the same as Brandt et al. (2017):

$$
\text { inputtariff }_{i t}=\sum_{g \in G_{i}} \alpha_{g t} \cdot \text { outputtariff } f_{g t}
$$

Among which, i、t、g represent industry, year and input factors respectively. $G_{i}$ represents the input factors set of industry i. $a_{g t}$ represents the input proportion of factor $\mathrm{g}$, its calculation method is the input cost of factor $\mathrm{g}$ divided by the input cost of all factors in industry $\mathrm{i}$ :

$$
a_{g t}=\text { input }_{g t} / \sum_{g \in G_{i}} \text { input }_{g t}
$$

The proportion of input $\left(a_{g t}\right)$ can be calculated by using China's 2002 input-output table.

Then, using the results of output tariffs and input tariffs, and combining with the industrial structure of each city, referring to the methods of Topalova (2010), Kovak (2013) and Dix Carneiro and Kovak (2017, 2019), we measure the regional tariff change index (RTC) at the city level:

$$
\begin{gathered}
R T C_{c}=-\sum_{j} \lambda_{j c, 2000} \Delta \text { Tariff }_{j} \\
\lambda_{j c, 2000}=\frac{L_{j c, 2000}}{\sum_{j} L_{j c, 2000}}
\end{gathered}
$$

Among which, Tariff $f_{j}$ represents the output tariffs or input tariffs of industry $\mathrm{j}$, and $\Delta$ Tariff $_{j}$ represents the tariff change from 2000 to 2010, which equals the tariff in 2010 minus the tariff in 2000. Therefore, we can calculate the tariff change of output tariffs and input tariffs. $L_{j c}$, 2000 represents the number of labor force employed by industry $\mathrm{j}$ in City $\mathrm{c}$ in 2000 , and $\lambda_{j c, 2000}$ represents the employment share of industry $\mathrm{j}$ in the city. We use $\lambda_{j c, 2000}$ as the weight to calculate the change range of output and input tariffs in the city. The greater the $R T C_{c}$, the higher the degree of trade liberalization of the city.

\section{Results}

\subsection{Basic Results}

Table 1 reports the regression results of output tariffs on total employment, formal employment and informal employment in the city labor market. In the table, columns (1), (2) and (3) only control the province fixed effect, while columns (4), (5) and (6) control the economic and social characteristic variables that will affect city employment. The regression results show that the coefficient sign of total employment and informal employment is positive, which is significant at the level of $1 \%$. The level of trade liberalization in cities is positively related to the scale of total employment and informal employment. But the coefficient of formal employment is not significant. According to the regression results, we can draw the following conclusions: the final product trade liberalization promotes the total employment and informal employment scale of the city labor market, but the effect on formal employment is not obvious. In a comprehensive view, the greater the tariff of the main industries in a city falls, the more obvious the effect of promoting employment. 
Table 1. The impact of output tariffs on formal and informal employment

\begin{tabular}{|c|c|c|c|c|c|c|}
\hline & (1) & (2) & (3) & (4) & (5) & (6) \\
\hline & Formal & Informal & Total & Formal & Informal & Total \\
\hline \multirow[t]{2}{*}{ RTC } & -0.135 & $6.706^{* * *}$ & $6.571^{* * *}$ & -0.239 & $6.573^{* * *}$ & $6.334^{* * *}$ \\
\hline & $(-0.25)$ & $(6.67)$ & $(6.42)$ & $(-0.25)$ & $(5.16)$ & $(4.13)$ \\
\hline \multirow[t]{2}{*}{ externalpop } & & & & $1.638^{* * *}$ & $5.287^{* * *}$ & $6.925^{* * *}$ \\
\hline & & & & (12.64) & $(4.76)$ & $(5.23)$ \\
\hline \multirow[t]{2}{*}{ humancapital } & & & & $0.763^{* * *}$ & $2.135^{* * *}$ & $2.898^{* * *}$ \\
\hline & & & & $(9.24)$ & $(4.87)$ & $(7.12)$ \\
\hline \multirow[t]{2}{*}{ ruralpop } & & & & $1.104^{* * *}$ & $3.131^{* * *}$ & $4.235^{* * *}$ \\
\hline & & & & (3.04) & $(7.75)$ & $(5.35)$ \\
\hline \multirow[t]{2}{*}{ _cons } & $98.206^{* * *}$ & $208.30^{* * *}$ & $306.51^{* * *}$ & -5.455 & 3.305 & -2.15 \\
\hline & $(20.40)$ & (23.39) & (33.84) & $(-0.09)$ & $(0.06)$ & $(-0.02)$ \\
\hline province FE & Yes & Yes & Yes & Yes & Yes & Yes \\
\hline$N$ & 262 & 262 & 262 & 262 & 262 & 262 \\
\hline $\mathrm{R} 2$ & 0.513 & 0.698 & 0.605 & 0.637 & 0.751 & 0.724 \\
\hline
\end{tabular}

Notes. $* \mathrm{p}<0.1, * * \mathrm{p}<0.05, * * * \mathrm{p}<0.01, \mathrm{t}$-value in brackets.

Table 2 reports the regression results of the change of input tariffs on total employment, formal employment and informal employment in the urban labor market. Similarly, columns (1), (2) and (3) in the table only control the province fixed effect, while columns (4), (5) and (6) add relevant control variables. Similar to the regression results of final goods trade liberalization, the coefficient sign of total employment and informal employment is positive, which is significant at the level of $1 \%$. But the coefficient of formal employment is not significant. The level of intermediate goods trade liberalization is positively related to the total employment and the scale of informal employment. The liberalization of intermediate goods trade promotes the total employment and informal employment scale of the city labor market, but it has no obvious effect on formal employment. Moreover, the lower the tariff of urban main industries, the more obvious the effect of promoting employment.

Table 2. The impact of input tariffs on formal and informal employment

\begin{tabular}{|c|c|c|c|c|c|c|}
\hline & (1) & (2) & (3) & (4) & (5) & (6) \\
\hline & Formal & Informal & Total & Formal & Informal & Total \\
\hline \multirow[t]{2}{*}{ RTC } & 1.102 & $17.572^{* * *}$ & $18.674^{* * *}$ & 0.022 & $17.835^{* * *}$ & $17.857^{* * *}$ \\
\hline & $(0.61)$ & (7.04) & $(7.58)$ & $(0.01)$ & (6.34) & (5.89) \\
\hline \multirow[t]{2}{*}{ externalpop } & & & & $2.036^{* * *}$ & $6.182^{* * *}$ & $8.218^{* * *}$ \\
\hline & & & & $(9.54)$ & $(3.67)$ & $(9.23)$ \\
\hline \multirow[t]{2}{*}{ humancapital } & & & & $1.114^{* * *}$ & $2.865^{* * *}$ & $3.979^{* * *}$ \\
\hline & & & & $(8.38)$ & $(3.15)$ & $(5.24)$ \\
\hline \multirow[t]{2}{*}{ ruralpop } & & & & $1.583^{* * *}$ & $4.196^{* * *}$ & $5.779^{* * *}$ \\
\hline & & & & (3.04) & $(9.55)$ & (11.36) \\
\hline \multirow[t]{2}{*}{ _cons } & $88.793^{* * *}$ & $140.317^{* * *}$ & $229.11^{* * *}$ & -6.209 & -83.476 & -89.685 \\
\hline & $(6.80)$ & $(7.75)$ & $(12.82)$ & $(-0.11)$ & $(-1.42)$ & $(-1.03)$ \\
\hline province FE & Yes & Yes & Yes & Yes & Yes & Yes \\
\hline$N$ & 262 & 262 & 262 & 262 & 262 & 262 \\
\hline $\mathrm{R} 2$ & 0.487 & 0.755 & 0.650 & 0.631 & 0.783 & 0.726 \\
\hline
\end{tabular}

Notes. $* \mathrm{p}<0.1, * * \mathrm{p}<0.05, * * * \mathrm{p}<0.01, \mathrm{t}$-value in brackets.

Compared with the results in table 1 and table 2, the regression coefficient of total employment and formal employment in table 2 is far greater than that in table 1, which shows that the promotion effect of intermediate goods trade liberalization on total employment and informal employment is greater than that of final goods trade liberalization. It can be seen that the liberalization of intermediate goods trade plays a more significant role in promoting employment. Moreover, it mainly promotes the increase of employment in informal labor market, and the increase of total employment is mainly driven by informal employment.

The trade liberalization of final goods and intermediate goods has a significant and regional heterogeneous effect 
on informal employment, but it has no significant impact on formal employment, which is caused by the difference between formal employment and informal employment itself and the heterogeneity of regional economic environment. First of all, in terms of regional economic environment, Shi Bingzhan and Zhang Xia (2017) pointed out that after China's accession to the WTO, processing trade flourished and developed in the eastern coastal areas, it can be seen that the import competition brought about by trade liberalization varies among regions. Zhang Jie et al. (2014) also pointed out that the final purpose of processing trade import intermediate goods is to export processed products, and the import brought by trade liberalization ultimately promotes the expansion of export scale. Due to the regional heterogeneity of import competition, this export expansion driven by import competition also has heterogeneity between regions. Secondly, in terms of the differences between formal employment and informal employment, the employees of processing trade enterprises are mostly transferred from the rural surplus labor force with low skill level and low salary, that is, informal employment. So the import competition and export expansion effect of trade liberalization improve the scale of informal employment. In addition, formal employment has signed a perfect employment contract, which is protected by various labor policies. The cost of terminating the contract is very large for enterprises and workers. Compared with formal employment, informal employment requires simple and flexible procedures, low wage level, and less protection. For employers and employees, informal employment flexibility is relatively large. When impacted by changes in tariff level, enterprises can flexibly adjust the number of employees. Enterprises with formal employment as the main form of employment choose to cope with the impact of trade liberalization by changing the wages of employees. So the temporary nature of informal employment makes it more responsive to shocks of liberalization at first, while the formal may lag. Goldberg and pavcnik (2003) also pointed out that enterprises with both formal and informal employment modes will adjust the demand for informal employment as the first choice when facing the trade liberalization.

Another reason for the regional heterogeneity of trade liberalization on formal and informal employment effects may be the different mobility of the two employment groups. We know that the traditional trade theory assumes that there are no barriers to the flow of factors, and the impact of tariff level changes will eliminate the differences between departments and regions through the flow and redistribution of factors between departments and regions. However, the reality is not so ideal. There are various natural and man-made obstacles in the flow of labor between regions and sectors, which leads to the lower mobility of formal employment than informal employment. Yan Shanping (2006) pointed out that the migrant workers in a city prefer to work in the informal sector. These workers have high mobility and passively shift jobs between different informal sectors, but it is difficult to move from the informal sector to the formal sector. The local residents mainly adopt the formal employment mode, and their mobility is lower than that of the outsiders. Only when they have a better career prospect can they consider changing their jobs actively. On the other hand, the informal sector, such as processing trade enterprises, prefers the informal employment mode and tries to avoid signing binding contracts with informal employment, so as to facilitate the increase and decrease of the number of employees at any time. This leads to the instability of informal employment, coupled with the restrictions of income level and household registration policy, these people can only migrate frequently between their hometown and different workplaces, relying on mobility to balance work and life. For the workers in formal employment, they will consider the factors of work, family and life, and then make mobility decisions. Moreover, the migration of formal workers is more for the long-term settlement in the future, and they will not change their workplace frequently.

Based on the above analysis, we can conclude that the regional heterogeneity of the impact of trade liberalization on formal and informal employment is different. The impact of trade liberalization on formal labor market is mainly reflected in the regional heterogeneity of wages, while the impact on informal labor market is mainly reflected in the regional heterogeneity of employment scale.

\subsection{Endogeneity and Robustness Test}

Although the city level tariff change index RTC constructed in this paper is exogenous, it may be affected by some policy changes. In order to avoid the endogenous problems caused by this kind of influence, it is more reasonable to measure the level of trade liberalization of cities by using the bound tariff rate in the schedule of tariff concessions promised by China's accession to the WTO. The bound tariff rate has been determined before China's accession to the WTO, and is not affected by the subsequent domestic policies. The index of trade liberalization at the city level calculated by the bound tariff rate is more exogenous. Therefore, we recalculate the output and input tariff change indicators of 262 cities by using the bound tariff rate, and make regression. On the one hand, it is a solution to the endogenous problem. On the other hand, we use the regression to test the robustness of the benchmark regression. Table 3 reports the regression results of bound tariff, which show that the benchmark regression results are robust. 
Table 3. The impact of bound tariffs on formal and informal employment

\begin{tabular}{ccccccccc}
\hline & & $(1)$ & $(2)$ & $(3)$ & $(4)$ & $(5)$ & $(6)$ \\
\cline { 2 - 8 } & \multicolumn{3}{c}{ Output tariffs } & \multicolumn{3}{c}{ Input tariffs } \\
\cline { 2 - 8 } & Formal & Informal & Total & Formal & Informal & Total \\
\hline RTC-bound & -0.376 & $6.217^{* * *}$ & $5.841^{* * *}$ & -0.112 & $16.921^{* * *}$ & $16.809^{* * *}$ \\
& $(-0.42)$ & $(5.54)$ & $(4.20)$ & $(-0.04)$ & $(6.64)$ & $(5.94)$ \\
& _cons & -6.104 & 15.284 & 9.18 & -5.504 & -64.255 & -69.759 \\
& $(-0.11)$ & $(0.26)$ & $(0.10)$ & $(-0.10)$ & $(-1.12)$ & $(-0.80)$ \\
Control var & Yes & Yes & Yes & Yes & Yes & Yes \\
province FE & Yes & Yes & Yes & Yes & Yes & Yes \\
$N$ & 262 & 262 & 262 & 262 & 262 & 262 \\
R2 & 0.623 & 0.738 & 0.699 & 0.632 & 0.758 & 0.739 \\
\hline
\end{tabular}

Notes. $* \mathrm{p}<0.1,{ }^{* *} \mathrm{p}<0.05, * * * \mathrm{p}<0.01, \mathrm{t}$-value in brackets.

\section{Conclusion and Policy Implications}

At the city level, this paper verifies the heterogeneity effect of trade liberalization on the employment of labor market in different cities of China. It can be seen from the empirical results that the more the tariff of the main industries in a region falls, the greater the growth of total employment and informal employment in the region. The eastern coastal areas of China have a more developed economy and its industrial emphasis facing larger tariff cuts, while the western areas are relatively less developed and its industrial emphasis facing smaller tariff cuts. Correspondingly, the employment situation in the eastern areas is relatively prosperous, absorbing a large number of informal employments.

In recent years, trade protectionism has prevailed, and the trade war between China and the United States has continued. Based on the conclusion of this paper, trade protectionism and anti-globalization policies will have a great impact on China's informal labor market, moreover, because of the low employment quality and income level of informal employees, the informal workers are more vulnerable to the impact of trade liberalization. Once the informal workers, accounting for more than $50 \%$ of China's total labor, can't digest the impact of international trade, it will bring a huge crisis to the overall Chinese labor market. Therefore, the focus of our foreign trade policy in the next round should be mainly on the adjustment of foreign trade structure. The transformation and upgrading of the foreign trade structure will drive the transformation and upgrading of economic structure. Protection policy and skills training should be provided for informal workers, to drive the balanced development of regional labor market, improve the anti-risk ability of labor market, and serve the people's life stability and economic development.

The policy implications of this paper are as follows. First, in China's new round of trade liberalization, we should strengthen the construction of inland areas, promote the opening-up process of the central and western regions, actively undertake the industries transferred from the eastern region, drive the industrial development of the central and western regions, form export-oriented industrial clusters, rationalize the industrial layout, and promote coordinated regional development, so as to promote the regional employment. Secondly, we should promote the innovation and development of processing trade, optimize the import structure, promote the upgrading of foreign trade, and promote the development of medium and high-end industries, which also plays an important role in improving the quality of employment. Finally, we should standardize the labor employment system, and strengthen the skill training of workers, especially informal employees. We should protect the legitimate rights and interests of informal employees and gradually guide them to "regularize" their employment, pay attention to solve structural employment contradictions and improve the quality of employment.

\section{References}

Arias, J., Artuc, E., Lederman, D., \& Rojas, D. (2018). Trade, Informal Employment and Labor Adjustment Costs. Journal of Development Economics, 133, 396-414. https://doi.org/10.1016/j.jdeveco.2018.03.006

Autor, D., Dorn, D., \& Hanson, G. H. (2013). The China Syndrome: Local Labor Market Effects of Import Competition in the United States. The American Economic Review, 103(6), 2121-2168. https://doi.org/10.1257/aer.103.6.2121

Bartik, T. (1991). Who Benefits from State and Local Economic Development Policies? Kalamazoo, MI: W. E.Upjohn Institute for Economic Research. https://doi.org/10.17848/9780585223940 
Bartik, T. (2006). How Do the Effects of Local Growth on Employment Rates Vary with Initial Labor Market Conditions. Upjohn Institute working paper, No 09-148. https://doi.org/10.17848/pol2015-005

Brandt, L., Van Biesebroeck, J., Wang, L., \& Zhang, Y. (2017). WTO Accession and Performance of Chinese Manufacturing Firms. American Economic Review, 107(9), 2784-2820. https://doi.org/10.1257/aer.20121266

Costa, F., Garred, J., \& Pessoa, J. P. (2016). Winners and Losers from a Commodities-for-Manufactures Trade Boom. Journal of International Economics, 102, 50-69. https://doi.org/10.1016/j.jinteco.2016.04.005

Dix-Carneiro, R., \& Kovak, B. K. (2017). Trade Liberalization and Regional Dynamics. The American Economic Review, 107(10), 2908-2946. https://doi.org/10.1257/aer.20161214

Dix-Carneiro, R., \& Kovak, B. K. (2015). Trade Liberalization and the Skill Premium: A Local Labor Markets Approach. The American Economic Review, 105(5), 551-557. https://doi.org/10.1257/aer.p20151052

Dix-Carneiro, R., \& Kovak, B. K. (2019). Margins of Labor Market Adjustment to Trade. Journal of International Economics, 117, 125-142. https://doi.org/10.1016/j.jinteco.2019.01.005

Gerxhani, K. (2004). The Informal Sector in Developed and Less Developed Countries: A Literature Survey. Public choice, 120(3-4), 267-300. https://doi.org/10.1023/B:PUCH.0000044287.88147.5e

Goldberg, P. K., \& Pavcnik, N. (2003). The Response of the Informal Sector to Trade Liberalization. Journal of development Economics, 72(2), pp.463-496. https://doi.org/10.1016/S0304-3878(03)00116-0

Kovak, B. K. (2013). Regional Effects of Trade Reform: What is the Correct Measure of Liberalization? The American Economic Review, 103(5), 1960-1976. https://doi.org/10.1257/aer.103.5.1960

Li, J. C., Liu, B., \& Xu, Y. T. (2014). A study on the informal employment effect of China's trade opening. China Population Science, (4), 35-45.

Maiti, D., \& Marjit, S. (2008). Trade Liberalization, Production Organization and Informal Sector of the Developing Countries. Journal of International Trade and Economic Development, 17(3), 453-461. https://doi.org/10.1080/09638190802137125

Melitz, M. J. (2003). The impact of trade on intra-industry reallocations and aggregate industry productivity. Econometrica, 71(6), 1695-1725. https://doi.org/10.1111/1468-0262.00467

Shi, B. Z., \& Zhang, X. (2017). Distribution effect of consumer welfare in China's trade liberalization. Economics: Quarterly, (4), 189-216. https://doi.org/10.13821/j.cnki.ceq.2017.03.08

Topalova, P. (2010). Factor immobility and regional impacts of trade liberalization: Evidence on poverty from India. American Economic Journal: Applied Economics, 2(4), 1-41. https://doi.org/10.1257/app.2.4.1

Yan, S. P. (2006). The mobility of people in urban labor market and its decisive mechanism-an analysis of the new dual structure of big cities. Management World, (8), 14-23. https://doi.org/10.19744/j.cnki.11-1235/f.2006.08.002

Zhang, C. C. (2015). The impact of export on employment, wage and income inequality - the evidence based on micro data. Economics: Quarterly, 14(4), 1611-1630. https://doi.org/ 10.13821/j.cnki.ceq.2014.04.18

Zhang, J., Zheng, W. P., Chen, Z. Y. et al. (2014). Whether imports lead to exports: a micro interpretation of China's export miracle. World Economy, 37(6), 3-26.

Zhang, M. Z., Liu, D. R., \& Deng, M. (2014). The impact of regional trade liberalization on individual wage change: An Empirical Study Based on individual micro data of chns2000-2011. International trade issues, (9), 36-46. https://doi.org/ 10.13510/j.cnki.jit.2014.09.004

Zhou, S., \& He, B. (2017). Regional effect and dynamic impact of trade liberalization on China's informal employment: An Empirical Study Based on micro data. International Trade Issues, (11), 13-24.

Zhou, S., \& He, B. (2019). Trade Liberalization and Regional Employment Adjustment: Evidence from China's Prefecture-Level Cities. World Economy, 42(6), 119-142.

\section{Copyrights}

Copyright for this article is retained by the author(s), with first publication rights granted to the journal.

This is an open-access article distributed under the terms and conditions of the Creative Commons Attribution license (http://creativecommons.org/licenses/by/4.0/). 